\title{
Mechanisms and Sources of Resistance in Tropical Maize Inbred Lines to Chilo partellus Stem Borers
}

\author{
S. W. Munyiri ${ }^{1,2}$, S. N. Mugo ${ }^{3}$, M. Otim ${ }^{4}$, J. K. Mwololo $^{1,5}$ \& P. Okori ${ }^{1}$ \\ ${ }^{1}$ Makerere University, Kampala, Uganda \\ ${ }^{2}$ Chuka University, Chuka, Kenya \\ ${ }^{3}$ International Maize and Wheat Improvement Center (CIMMYT), Nairobi, Kenya \\ ${ }^{4}$ National Crops Resources Research Institute (NACRRI), Kampala, Uganda \\ ${ }^{5}$ Pwani University, Kilifi, Kenya \\ Correspondence: S. W. Munyiri, Makerere University, P.O. Box 7062, Kampala, Uganda. Tel: 254-722-269-532. \\ E-mail: wanja_munyiri@yahoo.co.uk
}

Received: March 2, 2013 Accepted: May 22, 2013 Online Published: June 15, 2013

doi:10.5539/jas.v5n7p51 URL: http://dx.doi.org/10.5539/jas.v5n7p51

\begin{abstract}
Developing maize with durable resistance to maize stem borers could be enhanced by identifying genotypes with different mechanisms of resistance and pyramiding the resistances into high yielding genotypes. This study was carried out on 120 CIMMYT tropical maize inbred lines to identify the most important mechanisms of resistance that could be used to discriminate the germplasm into resistant or susceptible categories. The experiment was laid in an $\alpha$-lattice design, and replicated three times during the 2011/12 seasons. Traits measured were leaf toughness, stem penetrometer resistance, trichome density, stem sugar content, leaf damage, number of stem exit holes and stem cumulative tunnel length. A selection index was computed and categorized the 120 inbred lines into 33 resistant, 29 moderately resistant, 31 moderately susceptible and 27 susceptible. The most resistant lines were those derived from the CIMMYT multiple borer-resistant populations with CKSBL10039 being most resistant and CML395 most susceptible with indices of 0.49 and 1.84, respectively. Trichome density, leaf toughness and stem sugar content in that order were the most important traits in discriminating the lines into resistance and susceptible categories. More research is needed to classify the specific types of trichomes and sugars present in both resistant and susceptible inbred lines.
\end{abstract}

Keywords: leaf toughness, resistance, spotted stem borer, sugar content, trichome density

\section{Introduction}

Maize is an important staple food crop for the people in Kenya where it is grown on approximately 1.7 million hectares yielding about 2.3 million tons to feed an estimated 40 million people annually (FAOSTAT, 2010). Though there has been a gradual increase in maize production over the years since the 1970s, productivity has not matched the country's population growth rate (Mati, 2000). The decreasing maize production, repeated and widespread hunger since the nineteen eighties has been attributed to several biotic and abiotic stresses constraints (McCann, 2006). Sustainable solutions are needed to address the food shortage problem. In Kenya, maize stem borers accounts for $13.5 \%$ annual losses, but damage depends on the maize variety and the stage of attack (De Groote, 2002). Chilo partellus Swinhoe (Lepidoptera: Crambidae), a highly invasive stem borer, has become the most important maize stem borer in Kenya since its introduction in the 1930s (Mbapila, Overholt, \& Kayumbo, 2002). In a stem borer distribution study done in Kenya, about $54 \%$ of the recovered larvae were C.partellus Swinhoe (Crambidae), 40\% Busseola fusca (Fuller) (Noctuidae), 4\% Sesamia calamistis Hampson (Noctuidae) and 1\% Chilo orichalcociliellus (Strand) (Crambidae), the rest were minor borer species (Ong'amo et al., 2006).

Several attempts have been made to control stem borers, including C. partellus. The nature of stem borer larvae development within the host plant, however, hinders effective control using the standard control measures. Pesticides are mostly not accessible to farmers due to high costs. There are also concerns about human and environmental health, as well as possibilities of resistance build up among stem borers to pesticides. Due to the high costs of pesticides, farmers often resign to using no control measures at all. Host plant resistance (HPR) is important because it is packaged in the seed, causes no hazard to the environment and is compatible with other 
methods of control. In HPR, three types of resistance mechanisms are recognized i.e. non-preference (antixenosis), antibiosis and tolerance. Antixenosis refers to reduced plant attractiveness to the pest, while tolerance refers to the ability of the plant to withstand and recover from damage by the pest (Sarwar, 2012). In antibiosis type of resistance, the biology of the insect is affected leading to reduced longevity and reproduction, and increased insect mortality. Antibiosis decreases larval development as well as the number of larvae per plant, thereby decreasing the stem damage levels (Pimentel, 2002). All three components of resistance have been identified in stem borer resistant maize.

Maize inbred lines are an important resource for studies in genetics and breeding superior maize hybrids are produced by cross-pollinating two unrelated male and female inbred lines. Tropical inbred lines have been shown to have the greatest diversity for genetic structure capturing over $80 \%$ of the allelic diversity in landrace accessions, and are thus expected to hold a wide variety of resistance mechanisms (Liu et al., 2003). Broadening the genetic pool for maize breeding through identification of mechanisms of resistance in tropical inbred lines will form an important source of diversity for breeding against the stem borer damage in sub-Saharan Africa.

The major qualitative factor of resistance in maize to several maize insects is the hydroxamic acid, 2,4-dihydroxy7-methoxy-(2H)-1,4-benzoxazin-3-(4H)-one (DIMBOA) which has, however, been reported to decrease as the plant matures. DIMBOA is not always necessarily in higher levels in some resistant maize germplasm than in susceptible ones, suggesting that other factors contribute to resistance in maize beyond DIMBOA (Santiago, Souto, Sotelo, Butron, \& Malvar, 2003). Resistance may, therefore, involve different mechanisms that interact to determine the level of resistance for each germplasm.

Trichome density, leaf toughness and stem penetrometer resistance are important forms of physical resistance (antibiosis) against maize stem borers while stem sugar contents are reported to promote stem borer feeding in cereals (Padhi, 2004; Sarwar, 2012). Most plants produce morphological, physical structures and secondary compounds to function as defenses against herbivores. Trichomes can be glandular or non glandular and may contain several types of secondary compounds including methylketones which have been reported to improve resistance to pests and diseases in plants. In some plant species trichomes of juvenile plant varieties contain silica which imparts indigestibility to the herbivore pest (Kher, Dosdall, \& Carcamo, 2011). Higher levels of pith sugars have been reported to contribute to increased stem borer susceptibility in sorghum and rice irrespective of the varieties (Kumar, Sharma, \& Reddy, 2006; Sarwar, 2012). Leaf toughness was an important factor that influenced European corn borer feeding behavior (Malvar, Burtron, Ordas, \& Santiago, 2008). In selecting for European corn borer resistance, investigations on morphological changes proved that leaf toughness increased over cycles of selection and the trait was highly and negatively correlated to leaf damage (Bergvinson, Arnason, \& Hamilton, 1997). Stem penetrometer resistance is a type of physical resistance which results in reduced digestibility and/or increased hardness and abrasiveness of plant epidermal tissues (Arabjafari \& Jalali, 2007). The importance of stem penetrometer resistance is the prevention of larvae feeding on the stem pith during plant development causing weakening and lodging of the plants (Santiago et al., 2003). The weakening of the stem, a major carbohydrates storage point in maize plant may translate to reduced grain yield.

It is important to identify maize genotypes with different mechanisms of resistance so as to increase resistance levels and diversify the bases of resistance to the borer (Kvedaras \& Keeping, 2009). The presence of more than one mechanism of resistance with different effects on grain yield would improve the pattern of plant response, and ensure durability of the resistance. The objective of this study was, therefore, to determine the effects of leaf trichome density, leaf toughness, stem penetrometer resistance, and pith sugar content on resistance to Chilo partellus stem borer in selected tropical maize inbred lines.

\section{Materials and Methods}

\subsection{Site Description and Germplasm Used}

The trial was conducted at the Kenya Agricultural Research Institute (KARI) Kiboko Farm in the mid-altitude dry agro-ecological zone of Kenya. Kiboko lies at 950m above sea level, 37.75E, and 2.15S and receives about 530mm of rainfall per annum, coming in two short rainy seasons. Kiboko's maximum daily temperature is $35^{\circ} \mathrm{C}$ and a minimum of $14^{\circ} \mathrm{C}$. The soils are sandy clays. The germplasm was composed of one hundred and twenty (120) randomly selected CIMMYT maize inbred lines which included maize stem borer resistant inbred lines.

\subsection{Experimental Design}

The germplasm were grown in $\alpha$-lattice design replicated three times during the 2011/2012 short rains season. They were established in single row plots of seven meters i.e. 29 hills per row spaced at $75 \mathrm{~cm}$ and $25 \mathrm{~cm}$ between and within rows, respectively. Two seeds were sown per hill and later thinned to one plant per hill. Plowing and 
harrowing were carried out using tractor drawn implements, while planting, weeding, harvesting and shelling operations were performed manually. The trial was designed to accommodate destructive sampling of five plants per row. The plots, were, therefore marked with five strings in such a way as to separate the first one border plant, the next five plants (sampling plants), one protected plant, 10 plants to be infested, 10 pesticide protected plants, and two border plants in each row plot (Table 1). The first plant in each row was the border plant; the five consequent plants were used for destructive sampling data collection. The next 10 plants were each infested with five second instar $C$. partellus neonates three weeks after planting. All the other plants were protected from insect damage by applying an insecticide (Bulldock ${ }^{\circledR}$ granules-Beta-Cyfluthrin-AI) at the rate of $8 \mathrm{~kg} / \mathrm{ha}$, concurrently during infestation. The crop was rainfed but supplemental irrigation was applied as needed. Fertilizers were applied at the rate of $60 \mathrm{~kg} / \mathrm{ha} \mathrm{N}$ and $102 \mathrm{~kg} / \mathrm{ha} \mathrm{P}_{2} \mathrm{O}_{5}$ at planting, and top-dressed at the rate of $48 \mathrm{~kg} \mathrm{~N} / \mathrm{ha} 30 \mathrm{days}$ after planting.

Table 1. Field plot layout

\begin{tabular}{|c|c|c|c|c|c|c|}
\hline $\begin{array}{l}\text { Number of } \\
\text { plants }\end{array}$ & 1 & 5 & 1 & 10 & 10 & 2 \\
\hline Treatment & $\begin{array}{l}\text { Border } \\
\text { plant }\end{array}$ & $\begin{array}{l}\text { Destructive } \\
\text { sampling plants }\end{array}$ & $\begin{array}{l}\text { Border } \\
\text { plant }\end{array}$ & $\begin{array}{l}\text { Borer infested } \\
\text { plants }\end{array}$ & $\begin{array}{l}\text { Borer protected } \\
\text { plants }\end{array}$ & $\begin{array}{l}\text { Border } \\
\text { plants }\end{array}$ \\
\hline
\end{tabular}

\subsection{Data Collection}

Data on leaf damage (LD) was taken on visual rating score two weeks after infestation on each of the 10 infested plants on a scale of 1-9 (where, $1=$ no visible leaf damage and $9=$ plants dying) as a result of leaf damage as described by (Tefera, Mugo, Beyene, Karaya, \& Tende, 2011). Concurrently at the time of leaf damage scoring, leaf toughness in kilogram-force was taken on five randomly selected plants per row using a penetrometer (Model FT011, ALFOSINE-Italy). The youngest leaf with fully developed ligule was punched on the adaxial side 2-3 veins away from the mid-rib. Before the onset of flowering, 10 randomly selected leaf samples per plot were taken from the protected plants for trichome density count. The leaf below the first ear was cut at the center of the blade and a cork borer of $1 \mathrm{~cm}$ diameter was used to punch a maize leaf disk for which the number of trichome hairs was counted under a dissecting microscope (10X).

At the silking stage, stem penetrometer resistance was measured using a Penetrometer (FHT-803 fruit firmness tester software) with a fabricated needle. Five plants per row were punctured at the center of the second inter-node below the primary ear. The force was recorded in maximum kg-force. Stem pith sugar content was taken using a Brix Refractometer (r2mini Handheld Refractometer) after silking. The second inter-node below the primary ear was cut into ten $(10 \mathrm{~cm})$ pieces and a $1 \mathrm{~cm}$ radius cork borer used to extract the pith. The pith tissue was then squeezed to extract about two drops of juice onto the Refractometer sensor, and the sugar content reading expressed as a percentage (\%). At harvest, the numbers of stem borer exit holes (EH) were counted and the cumulative tunnel length (TL) in $\mathrm{cm}$ was measured after splitting the stems across the middle.

\subsection{Data Analysis}

All data collected were analyzed using PROC GLM (SAS, 2003). Genotypes were considered random effects. Analysis of variance was done and the means compared using Fishers protected least significant difference test (LSD) at $(\mathrm{P}<0.05)$. A multivariate analysis of variance within a canonical variate analysis was performed using the SAS package (Canonical discriminant analysis tool) to determine the most variable mechanism trait among the genotypes (SAS, 2003). To secure error control, coefficient correlation analysis was done for the mechanisms of resistance (trichome density, leaf toughness, sugar content and stem penetrometer resistance) and the damage parameters (leaf damage, exit holes and cumulative tunnel length) using canonical correlations.

A selection index based on the significant damage parameters was computed by summing up the ratios among values and dividing by the number of parameters summed up, as described by Tefera et al. (2011). Genotypes with selection index values of less than 0.8 were regarded as resistant, those between $0.8-1.0$ were considered moderately resistant, 1.0-1.2 were considered moderately susceptible, and over 1.2, were considered susceptible. 


\section{Results}

\subsection{Canonical Discriminant Analysis and Correlations}

The ANOVA's univariate statistics showed significant differences among the inbred lines for leaf toughness, sugar content, trichome density, leaf damage, number of exit holes and cumulative tunnel length i.e. the variables class means were therefore not equal to zero at $\mathrm{P}<0.05$. The most important resistance mechanisms in discriminating the inbred lines were trichome density, leaf toughness, and stem sugar content with canonical coefficient loadings in CAN1 of 1.59 , CAN2 of 1.22 , and CAN3 1.08, respectively (Table 2). The $\mathrm{R}^{2}$ values were 0.80 for trichome density, 0.66 for leaf toughness and 0.61 for sugar content. The most important damage parameters for discriminating the inbred lines were leaf damage, number of exit holes, and tunnel length with canonical coefficient loadings in CAN1 of 1.25 , CAN2 of 1.13 , and CAN3 of 1.42 , respectively. The $\mathrm{R}^{2}$ values for damage parameters were 0.64 for leaf damage, 0.48 for exit holes and 0.43 for tunnel length. All the multivariate's statistics, Wilk's Lambda, Pillai's Trace, Hotelling-Lawley Trace and Roy's Greatest root tests, for the null hypothesis test that the current canonical correlation and all the smaller ones are zero showed that none of them was zero $(\operatorname{Pr}>0.0001)$. The alternate hypothesis was adopted as the above significant likelihood ratio showed that the current canonical correlation and all the smaller ones were not zero meaning that all the three damage parameters were highly correlated (Table 2).

Table 2. Canonical discriminant analyses for mechanisms of resistance to maize stem borer and damage traits in tropical inbred lines

\begin{tabular}{|c|c|c|c|c|c|c|c|c|c|}
\hline Mechanisms Traits & Total SD & Pooled SD & Between SD & $\mathbf{R}^{2}$-Value & $\operatorname{Pr}>\mathbf{F}$ & CAN1 & CAN2 & CAN3 & $\begin{array}{c}\text { Attributed } \\
\text { Variation }\end{array}$ \\
\hline Leaf toughness & 0.044 & 0.036 & 0.036 & 0.66 & 0.002 & -0.264 & 1.235 & -0.219 & 24 \\
\hline Sugar content & 2.474 & 2.193 & 1.929 & 0.61 & 0.008 & -0.073 & 0.3605 & 1.079 & 16 \\
\hline Stem hardness & 0.734 & 0.707 & 0.538 & 0.53 & $0.211 \mathrm{NS}$ & -0.142 & -0.3903 & 0.211 & 12 \\
\hline Trichome density & 5.046 & 3.190 & 4.521 & 0.80 & $<.0001$ & 1.594 & 0.1210 & 0.029 & 46 \\
\hline \multicolumn{10}{|l|}{ Damage traits } \\
\hline Leaf damage & 0.805 & 0.594 & 0.643 & 0.64 & $<.0001$ & 1.251 & -0.5350 & -0.152 & 59 \\
\hline No. of exit holes & 1.387 & 1.228 & 0.959 & 0.48 & $<.0001$ & 0.135 & 1.1304 & -0.988 & 24 \\
\hline Tunnel length & 3.89 & 3.587 & 2.575 & 0.43 & 0.002 & 0.247 & -0.0485 & 1.417 & 17 \\
\hline
\end{tabular}

$\mathrm{NS}=$ not significant at $\mathrm{P}>0.05$.

Canonical correlation indicated that the two sets of variables, mechanisms of resistance and damage parameters were not correlated. The first canonical correlation is the greatest possible multiple correlation with the classes that can be achieved by using a linear combination of the quantitative variables. The Wilks' Lambda, one of the four multivariate statistics that tests the null hypothesis that the canonical correlations and all the smaller ones are zero was not significant $(\operatorname{Pr}>0.1036)$, and so were the Pillai's $\operatorname{Trace}(\operatorname{Pr}>0.1162)$ and Hotelling-Lawley Trace $(0.946)$ (Table 3). This strongly indicated that there was no linear relationship between the damage parameters evaluated (leaf damage, exit holes and tunnel length) and the resistance mechanisms measured (trichome density, leaf toughness, sugar content and stem penetrometer resistance).

Table 3 Summary statistics of the canonical correlations between the two sets of variables (damage parameters and mechanisms of resistance) in 120 tropical inbred lines

\begin{tabular}{ccccccccc}
\hline CAN & $\begin{array}{c}\text { Canonical } \\
\text { Correlation }\end{array}$ & $\begin{array}{c}\text { Squared } \\
\text { Can correlation }\end{array}$ & $\begin{array}{c}\text { Eigen } \\
\text { Values }\end{array}$ & $\begin{array}{c}\text { Likelihood } \\
\text { ratio }\end{array}$ & $\begin{array}{c}\text { Approx. } \\
\text { F-Value }\end{array}$ & $\begin{array}{c}\text { Num } \\
\text { DF }\end{array}$ & $\begin{array}{c}\text { Den } \\
\text { DF }\end{array}$ & Pr>F \\
\hline \multirow{2}{*}{2} & 0.3656 & 0.1336 & 0.1543 & 0.852 & 1.56 & 12 & 299.3 & $0.1036 \mathrm{NS}$ \\
3 & 0.1026 & 0.0105 & 0.0106 & 0.9834 & 0.32 & 6 & 228 & $0.9268 \mathrm{NS}$ \\
& 0.0781 & 0.0061 & 0.0061 & 0.9939 & 0.35 & 2 & 111 & $0.7035 \mathrm{NS}$ \\
\hline
\end{tabular}

$\mathrm{NS}=$ not significant at $\mathrm{p}>0.05$ level. 


\subsection{Anova}

The analysis of variance (ANOVA) showed significant differences in all traits measured $(\mathrm{P}<0.05)$. The selection index categorized the inbred lines into 33 resistant $(<0.80), 29$ moderately resistant $(0.8-1.0), 31$ moderately susceptible (1.0-1.2) and 27 as susceptible ( $>1.2)$ (Figure 2). These figures deviate from the normal distribution curve as the lines were not all randomly selected since the most resistant (MBR inbred lines) had been deliberately selected. The most resistant lines were CKSBL10039 and MBR CKSBL10025 with indices of 0.50 and 0.52 , respectively. CML395 and CML312 were the most susceptible inbred lines with indices of 1.85 and 1.65 , respectively.

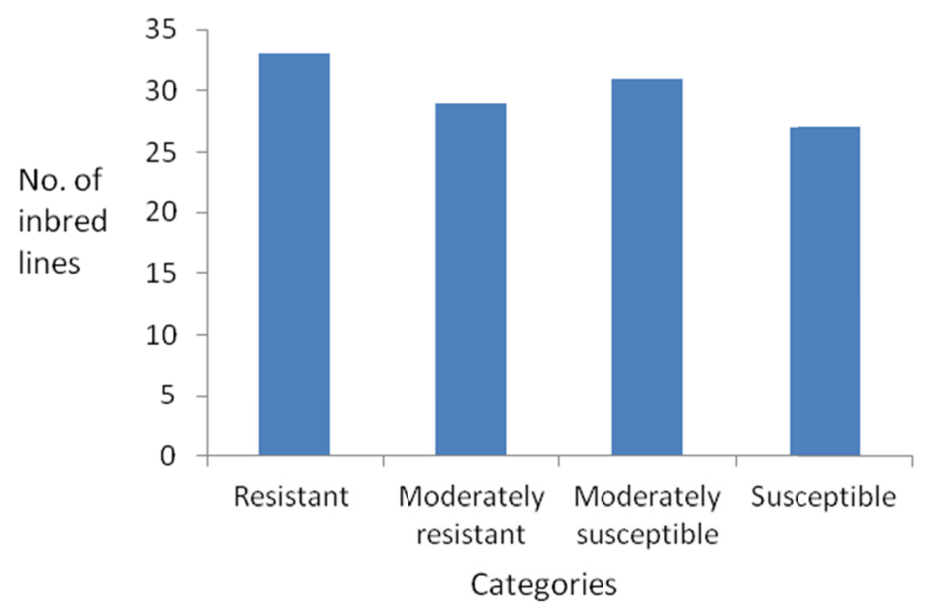

Figure 2a. Representation of the different categories of resistance and susceptibility in 120 inbred lines

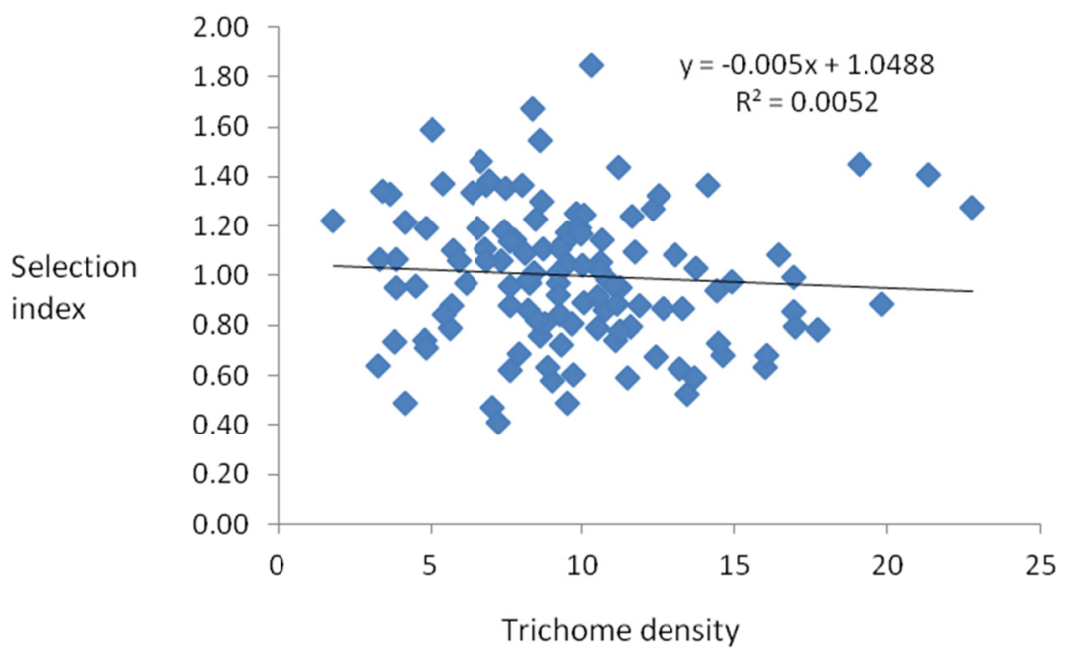

Figure $2 \mathrm{~b}$. Relationship between trichome density and selection index in 120 tropical inbred lines

The means for leaf damage, stem borer exit holes and cumulative stem tunneling were $2.22,3.69$ and $12.70 \mathrm{~cm}$, respectively (Table 4). Leaf damage was highest in CML254 at 5.94, a susceptible line with an index of 1.37. The lowest score was 2.05 in CKSBL10035, with an index of 0.59. Highest number of exit holes was 7.94 in CML395 which was also the most susceptible with an index of 1.85, while the lowest was 0.91 in CKSBL10039 which was also the most resistant inbred line. The cumulative tunnel length damage was shortest in CKSPL10256 (4.99 cm) and longest in CML197 at $32.47 \mathrm{~cm}$ which was highly susceptible with an index of 1.53 . All the damage parameters were significantly and positively correlated, the highest correlation was between exit holes and tunnel length $\left(r=0.7^{* *}\right)$, a suggestion that any of the two parameters could be a good measure for resistance. 
Table 4. Means of the twenty most resistant and susceptible inbred lines for traits measured

\begin{tabular}{|c|c|c|c|c|c|c|c|c|c|}
\hline Entry & Name & Index & LD & EH & TL & TD & LT & $\% \mathrm{SC}$ & SH \\
\hline 111 & CKSBL10039 & 0.50 & 1.90 & 1.29 & 3.61 & 13.81 & 0.33 & 6.27 & 3.17 \\
\hline 113 & CKSBL10025 & 0.52 & 1.80 & 1.86 & 3.12 & 2.92 & 0.20 & 10.07 & 2.93 \\
\hline 116 & CKSBL10026 & 0.53 & 1.89 & 1.50 & 4.07 & 10.58 & 0.24 & 9.21 & 2.95 \\
\hline 33 & CKSBL10025 & 0.56 & 1.61 & 2.06 & 5.20 & 5.96 & 0.19 & 9.93 & 2.59 \\
\hline 103 & CKSBL10014 & 0.57 & 2.08 & 1.54 & 4.44 & 8.76 & 0.18 & 7.90 & 3.12 \\
\hline 35 & CKSBL10026 & 0.58 & 1.79 & 1.74 & 5.93 & 10.35 & 0.22 & 9.39 & 2.86 \\
\hline 20 & CKSBL10014 & 0.64 & 2.41 & 1.78 & 4.59 & 8.17 & 0.20 & 8.31 & 3.04 \\
\hline 57 & CML488 & 0.67 & 2.14 & 1.59 & 7.88 & 10.65 & 0.16 & 11.82 & 2.45 \\
\hline 115 & CKSBL10004 & 0.69 & 1.97 & 1.85 & 8.55 & 7.92 & 0.24 & 8.15 & 3.72 \\
\hline 36 & CKSBL10004 & 0.69 & 1.76 & 2.51 & 7.58 & 9.75 & 0.29 & 8.44 & 3.79 \\
\hline 1 & CKSBL10027 & 0.71 & 2.18 & 1.87 & 8.02 & 5.68 & 0.23 & 6.62 & 3.48 \\
\hline 95 & CKSPL10206 & 0.72 & 2.35 & 2.42 & 5.67 & 10.09 & 0.20 & 7.66 & 2.52 \\
\hline 15 & CKSBL10040 & 0.72 & 2.13 & 2.08 & 8.12 & 10.88 & 0.18 & 5.80 & 2.98 \\
\hline 29 & CKSBL10007 & 0.73 & 1.85 & 2.05 & 9.99 & 11.94 & 0.16 & 9.13 & 3.86 \\
\hline 23 & CKSBL10035 & 0.74 & 1.82 & 2.28 & 10.04 & 7.61 & 0.24 & 9.51 & 2.87 \\
\hline 6 & CKSBL10045 & 0.76 & 2.06 & 2.48 & 8.47 & 14.27 & 0.19 & 8.30 & 3.23 \\
\hline 31 & CKSBL10043 & 0.76 & 2.18 & 2.76 & 6.93 & 6.35 & 0.22 & 11.13 & 2.98 \\
\hline 28 & CKSBL10034 & 0.76 & 1.72 & 2.77 & 9.70 & 7.97 & 0.21 & 7.81 & 3.35 \\
\hline 26 & CKSBL10001 & 0.77 & 1.69 & 3.08 & 9.21 & 11.93 & 0.26 & 10.77 & 2.71 \\
\hline 19 & CKSBL10082 & 0.78 & 1.85 & 2.99 & 8.74 & 15.14 & 0.20 & 8.52 & 3.25 \\
\hline 46 & CZL03014 & 1.24 & 2.62 & 4.36 & 17.28 & 4.88 & 0.20 & 8.67 & 2.52 \\
\hline 22 & CKSBL10042 & 1.28 & 2.35 & 4.63 & 19.26 & 11.49 & 0.25 & 7.26 & 3.88 \\
\hline 78 & CKSPL10081 & 1.29 & 2.57 & 5.18 & 16.79 & 10.67 & 0.23 & 10.33 & 3.70 \\
\hline 74 & CKSPL10070 & 1.30 & 2.07 & 5.75 & 17.84 & 4.32 & 0.22 & 8.83 & 3.06 \\
\hline 7 & CKSPL10344 & 1.33 & 2.30 & 5.31 & 19.26 & 8.70 & 0.18 & 9.33 & 3.29 \\
\hline 110 & CKSBL10041 & 1.35 & 2.61 & 4.98 & 19.36 & 13.38 & 0.22 & 8.94 & 3.68 \\
\hline 58 & CZL00003 & 1.35 & 2.23 & 5.40 & 20.11 & 8.40 & 0.22 & 9.61 & 3.27 \\
\hline 98 & CKSPL10224 & 1.37 & 2.64 & 5.28 & 19.08 & 10.86 & 0.20 & 6.52 & 3.11 \\
\hline 49 & DTPWC9-F115-1-4-1-1-B-B-\#-\# & 1.39 & 2.42 & 6.20 & 17.59 & 4.63 & 0.19 & 10.16 & 3.00 \\
\hline 89 & CKSPL10136 & 1.40 & 2.43 & 4.97 & 22.17 & 9.16 & 0.20 & 6.39 & 3.67 \\
\hline 97 & CKSPL10218 & 1.44 & 2.73 & 6.70 & 16.11 & 10.29 & 0.16 & 8.83 & 2.80 \\
\hline 34 & CML442 & 1.44 & 2.12 & 6.72 & 19.66 & 22.07 & 0.24 & 10.01 & 2.45 \\
\hline 16 & CML264 & 1.47 & 2.33 & 5.81 & 22.79 & 13.15 & 0.19 & 8.68 & 3.01 \\
\hline 104 & CKSBL10013 & 1.48 & 2.45 & 5.68 & 22.62 & 10.00 & 0.22 & 10.88 & 2.99 \\
\hline 25 & CML202 & 1.49 & 2.33 & 5.79 & 23.33 & 13.92 & 0.19 & 8.90 & 3.27 \\
\hline 27 & CML204 & 1.51 & 2.42 & 5.89 & 23.53 & 8.92 & 0.14 & 10.69 & 1.97 \\
\hline 42 & CML197 & 1.53 & 1.95 & 6.52 & 24.85 & 3.48 & 0.20 & 7.53 & 2.68 \\
\hline 62 & CZL01005 & 1.59 & 2.59 & 6.50 & 23.56 & 7.76 & 0.20 & 8.21 & 2.38 \\
\hline 10 & CML312 & 1.64 & 1.89 & 7.23 & 26.77 & 7.62 & 0.11 & 6.01 & 2.47 \\
\hline 3 & CML395 & 1.85 & 2.85 & 8.12 & 26.12 & 10.12 & 0.19 & 9.86 & 2.33 \\
\hline Trial Mean & & & 3.23 & 2.63 & 6.29 & 9.67 & 0.19 & 8.91 & 3.13 \\
\hline $\mathrm{CV}$ & & & 19.01 & 42.10 & 51.6 & 33.6 & 18.90 & 9.31 & 19.35 \\
\hline LSD & & & 0.99 & 1.78 & 5.22 & 5.23 & 0.06 & 1.34 & 0.97 \\
\hline F-test & & & $<.0001$ & $<.0001$ & $<.0001$ & $<.0001$ & 0.0096 & $<.0001$ & 0.0002 \\
\hline
\end{tabular}

LD, leaf damage; EH, number of exit holes; TL, cumulative tunnel length; TD, trichome density; LT, leaf toughness; $\mathrm{SC} \%, \%$ stem sugar content; SPR, stem penetrometer resistance. 
Trichome density was highly and significantly different for the inbred lines $(\mathrm{P}<0.0001)$ and ranged from 1.23 in P300C5S1B-2-3-2-\#-\#-1-2-B-B-\#-B which was susceptible with an index of 1.21, to 27.04 in CML511 which was unexpectedly also susceptible in spite of the high trichome density, with an index of 1.45. CML442, a susceptible inbred line, was second with a similarly high trichome density of 22.07. The mean trial trichome density was 9.66.

The inbred lines showed high and significant differences in sugar content levels $(\mathrm{P}<0.0001)$. Sugar content ranged from 5.37 in CKSPL10343 which was moderately susceptible (1.12) to $12.61 \%$ in LPSC7-F86-3-1-1-1-BB-\#-B which was also moderately susceptible, with a mean of $8.91 \%$.

The inbred lines showed high and significant differences in leaf toughness $(\mathrm{P}<0.0001)$ ranging from $0.12-0.33 \mathrm{~kg}$-force, with a mean of $0.19 \mathrm{~kg}$-force. The highest leaf puncture force of $0.33 \mathrm{~kg}$ was in CKSBL10039 which was also the most resistant inbred line with the lowest index of 0.49. CKSBL10020, a line with an index of 0.98 was second best with a $0.29 \mathrm{~kg}$-force. The lowest leaf puncture-force (softest) was in CML312 (0.13kg-force a susceptible line with an index of 1.64.

The stem penetrometer resistance ranged from 1.91 to $4.79 \mathrm{~kg}$. The trial mean was $3.13 \mathrm{~kg}$. The highest penetrometer resistance was in DTPWC9-F104-5-4-1-1-B-B-\#-\# at 4.80kg-force, it was moderately resistance (0.92). The lowest penetrometer resistance (softest stem) was in LPSC7-F86-3-1-1-1-BB-\#-B at 1.91kg-force; it was moderately susceptible, and also had the highest percentage sugar content. Its selection index was 1.06. It was followed closely by CML395 with $1.93 \mathrm{~kg}$-force which was the most susceptible inbred line with an index of 1.85 (Table 4).

\section{Discussion}

\subsection{Trichome Density}

Canonical discriminant analysis showed that among the traits evaluated, trichome density was the best in discriminating the inbreds lines. Resistance to the stem borer generally increased with increasing trichome density as has been reported in earlier studies. Kumar (1992) and Dalin, Agren, Bjorkman, Huttunen, \& Karkkainen (2008) similarly reported that plant damage factors by herbivore insects generally decreased with increasing trichome density. Kumar, Reddy, and Sharma (2007) showed that ovipositional non-preference by stem borer on maize genotypes was due to the presence of trichomes. Handley, Ekbom and Agren (2005) reported that some types of trichomes contained secondary compounds which deterred feeding by a wide spectrum of insect herbivores. There were, however, some notable exceptions where some inbred lines with high trichome densities were susceptible while some with low trichome densities were resistant. The relationship between trichome density and the selection index was weak and negative (Figure 2). These findings suggest that several other mechanisms of resistance may have acted together to confer resistance, but these mechanisms were germplasm-dependent. While trichome density discriminated the inbred lines better into different resistant categories; it is possible that each inbred line had other different mechanisms of defense, or a combination of several mechanisms that were physiologically active. Novoa and Russel (1988) reported that resistance was mostly a result of the interaction of several structural and non structural factors, some of these were not evaluated in this trial. Trichomes could be glandular or non glandular and may contain several types of secondary compounds i.e. methylketones which improve resistance to pests and diseases in plants (Eyal et al., 2005). These differences in trichomes structures and sizes affect the efficiency of the trichomes in deterring feeding. Dalin et al. (2008) reported that the number and type of trichomes in a plant and trichome density varies within species and these are quantitatively inherited. A repeat of this trial with attention given to the examination of the types and structure of trichomes in the resistant and susceptible inbred lines would shed more light on the most effective type of trichomes in conferring resistance.

\subsection{Leaf Toughness}

Leaf toughness was the second best trait that discriminated the genotypes into resistant and susceptible categories. The most resistance inbred line, CKSBL10039, had the highest penetrometer resistance force ( $0.33 \mathrm{~kg}$-force), an indication of resistance through antibiosis for leaf feeding. The MBR inbred lines exhibited high penetrometer resistance, while most of the susceptible genotypes had lower leaf penetrometer resistance, a clear suggestion of the trait's importance in conferring resistance through antibiosis. Increased leaf toughness, therefore, enhances maize resistance to the stem borer. This observation agree with that of Chu and Horng (1991) and Sarwar (2012) who reported that leaf feeding by the stem borer was negatively correlated with leaf tissue hardness, an important factor in conferring resistance to stem borers.

\subsection{Stem Sugar Content (\%)}

Generally, genotypes with low to moderate stem sugar content fell into the resistant to moderately resistant categories. The most resistant inbreds CIMMYT MBR lines CKSBL10039 and CKSBL10027, with indices of 
0.49 and 0.71 had stem sugar contents $6.27 \%$ and 6.62, respectively. LPSC7-F86-3-1-1-1-BB-\#-B, P300C5S1B-2-3-2-\#-\#-1-2-B-B-\#-\# and CML204 which ranged between moderately susceptible to susceptible had the highest sugar contents of $12.61 \%, 11.42 \%$, and $11.03 \%$, respectively. While this was a possible indication that the sugar content played a key role in conferring resistance, several variations were noted where some inbred lines with low sugar content were moderately susceptible i.e. CML312, and a few with high stem sugar content were either resistant or moderately resistant i.e. CKSBL10025 (Table 4). There was, therefore, no clear cut trend for all germplasm, suggesting that resistance and susceptibility was germplasm-specific for a few inbred lines evaluated. It may be deduced that since there are different types of sugars, some specific types of sugars could have acted as anti-feedants while others might have promoted feeding. Canonical discriminant analysis indicated stem sugar content as the third best trait that would discriminate the inbreds. A further biochemical study categorizing the actual type of sugars present in resistant and susceptible germplasm would help categorize the specific sugars that contribute to stem borer resistance in maize and those that increase susceptibility. The general trends from the majority of the inbred lines evaluated in this study, however, agrees with previous reports by Arabjafari and Jalali (2007); Sarwar (2012) and Padhi (2004) that generally, susceptible maize varieties contained significantly higher percentages of stem sugars than in resistant varieties.

\subsection{Stem Penetrometer Resistance}

Susceptibility increased with decreasing penetrometer resistance. These results indicate that stem puncture resistance played a role in conferring resistance. As the larvae bores into the stem for more feeding awaiting pupation, more damage was caused on soft stems than on hard stems causing increased stem pith tunneling. The maize stem borer damages the stem through feeding on the pith and the vascular tissues placing the plant under physiological stress. In wild rice Padhi and Sen (2002) reported that non-preference was attributed to very hard and tough stems, since artificial infestation was carried out in this experiment, antibiosis was mostly the mode of resistance mechanism tested. The importance of stem penetrometer resistance was reported by Santiago et al (2003) as the prevention of larvae feeding on the stem pith during plant development which causes weakening and lodging of the plants. Arabjafari and Jalali (2007) also found stem penetrometer resistance to contribute a logical mechanism in lowering the penetration and the length of tunneling produced by stem borers consequently influencing the partitioning of photosynthates to the ear. Canonical discriminant analysis showed stem penetrometer resistance not to be significant in discriminating the inbred lines. These results suggested that stem penetrometer resistance may not be a strong trait to use as measure for resistance in the inbred lines.

\subsection{Damage Parameters}

Leaf damage score, number of borer exit holes and cumulative stem tunneling were important in measuring resistance. Leaf damage was, however, the most important in discriminating the genotypes followed by the number of borer exit holes and the cumulative tunnel length. In canonical discriminant analysis, the high canonical correlation among the damage traits was a strong suggestion that any of the traits could be used to evaluate genotypes for resistance to the stem borer. Canonical correlations between the damage parameters and the mechanisms of resistance were, however, not significant, a suggestion that other mechanisms of resistance could have inherently been active in the inbred lines.

\section{Conclusions}

It was concluded that the several mechanisms of resistance exist in tropical inbred lines with trichome density being the most promising indicator of resistance followed by leaf toughness and stem sugar content. More research is needed to classify the specific types of trichomes, the chemical composition and the specific sugars present in both resistant and susceptible inbred lines in order to identify the causes for some of the inconsistencies reported herein. While CIMMYT has developed several multiple borer resistant lines, the search for new and higher levels of resistance could be enhanced by combining different mechanisms into new inbred lines for hybrid production.

\section{Acknowledgements}

The Regional Universities Forum for Capacity Building in Agriculture (RUFORUM) and the Syngenta Foundation for Sustainable Agriculture through the Development of Resistant Maize to Stem Borer and Storage Insect Pests for Eastern and Southern Africa are appreciated for co-funding this research. Mr Joel Mbithi and Mr Patrick Chomba, Kiboko field staff are highly appreciated for their contributions to the success of this study. This is part of the first author's PhD research study. 


\section{References}

Arabjafari, K. H., \& Jalali, S. K. (2007). Identification and analysis of host plant resistance in leading maize genotypes against spotted stem borer, Chilo partellus (Swinhoe) (Lepidoptera: Pyralidae). Pakistan Journal of Biological Sciences, 10, 1885-1895. http://dx.doi.org.10.3923/pjbs.2007.1885.1895

Bergvinson, D. J., Arnason, J. T., \& Hamilton, R. I. (1997). Phytochemical changes during recurrent selection for resistance to European corn borer. Crop Science, 37, 1567-1572. http://dx.doi.org/10.2135/cropsci1997.0011183X003700050026x

Chu, Y. I., \& Horng, S. B. (1991). Infestation and reproduction of Asian cornborer on slag-treated corn plant. Chinese Journal of Entomology, 11, 19-24.

Dalin, P., Agren, J., Bjorkman, C., Huttunen, P., \& Karkkainen, K. (2008). Leaf Trichome Formation and Plant Resistance to Herbivory. In A. Schaller (Ed.), Induced Plant Resistance to Herbivory (p. 89-105). Springer Science+Business Media. http://dx.doi.org/10.1007/978-1-4020-8182-8_4

De Groote, H. (2002). Maize yield losses from stem borers in Kenya. Insect Science Applicata, 22, 89-96.

Eyal, F., Jihong, W., Yoko, I., John, E. F., David, R. G., John, O., \& Eran, P. (2005). Metabolic, genomic, and biochemical analyses of glandular trichomes from the wild tomato species Lycopersicon hirsutum identify a key enzyme in the biosynthesis of methylketones. The Plant Cell, 17, 1252-1267. http://dx.doi.org/10.1105/tpc.104

FAOSTAT. (2010). FAOSTAT Statistics Division: Agricultural Data Food and Agriculture Organization of the United Nations. Retrieved from http://faostat.fao.org/site/567/DesktopDefault.aspx?PageID=567\#ancor

Handley, R., Ekbom, B., \& Agren, A, (2005). Variation in trichome density and resistance against a specialist insect herbivore in natural populations of Arabidopsis thaliana. Ecological Entomology, 30, 284-292 http://dx.doi.org.10.1111/j.0307-6946.2005.00699.x

Keeping, M. G., \& Meyer, J. H. (2002). Calcium silicate enhances resistance of sugarcane to the African stalk borer Eldana saccharina Walker (Lepidoptera: Pyralidae). Agricultural and Forest Entomology, 4, 265-274. http://dx.doi.org.10.1046/j.1461-9563.2002.00150.x

Kher, S. V., Dosdall, L. M., \& Cárcamo, H. A. (2011). The Cereal Leaf Beetle: Biology, Distribution and Prospects for Control. Insects and Diseases, 4, 32-41.

Kumar, H., \& Saxena, K. N. (1992). Resistance in certain maize cultivars to first and third-instar Chilo partellus $\begin{array}{lllll}\text { larvae. Entomologia Experimentalis et } & \text { Applicata, } & 65,80 .\end{array}$ http://dx.doi.org.10.1111/j.1570-7458.1992.tb01629.x

Kumar, V. K., Sharma, H. C., \& Reddy, K. D. (2006). Antibiosis mechanism of resistance to spotted stem borer, Chilo partellus in sorghum. Sorghum bicolor, 25, 66-72.

Kumar, V. K., Reddy, K. D., \& Sharma, H. C. (2007). Expression of antixenosis and antibiosis components of resistance to spotted stem borer Chilo partellus in sorghum under greenhouse conditions. eJournal, 3, 1-4.

Kvedaras, O. L., \& Keeping, M. G. (2009). Silicon impedes stalk penetration by the borer Eldana saccharina in $\begin{array}{llllll}\text { sugarcane. Journal of } & \text { Applied }\end{array}$ http://dx.doi.org.10.1111/j.1570-7458.2007.00604.x

Liu, K., Goodman, M. Muse, S., Smith, J., Buckler, E., \& Doebley, J. (2003). Genetic structure and diversity among maize inbred lines as inferred from DNA microsatellites. Genetics, 165, 2117-2128.

Malvar, R. A., Burtron, A., Ordas, A., \& Santiago, R. (2008). Causes of natural resistance to stem borers in maize. In E. N. Burton, \& P. D. William (Eds.), Crop Protection Research Advances (pp. 57-100). New York: Nova Science Publishers Inc.

Mati, B. M. (2000). The influences of climate change on maize production in the semi-humid-semi arid areas of Kenya. Journal of Arid Environments, 46, 333-344. http://dx.doi.org.10.1006/jare.2000.0699

Mbapila, J. C., Overholt, W. A., \& Kayumbo, H. Y. (2002). Comparative development and population growth of an exotic stem borer, Chilo partellus (Swinhoe), and an ecologically similar congener, Chilo orichalcociliellus (Strand) (Lepidoptera: Crambidae). Insect Science Application, 22, 21-27. http://dx.doi.org/10.1017/S1742758400015022

McCann, J. C. (2006). Maize and Grace: Africa's encounter with a new world crop, 1500-2000. Cambridge: Harvard University Press. http://dx.doi.org/10.1017/S0165115300013504 
Novoa, A. D., \& Russel, W. A. (1988). Harvest Index Analysis in three improved maize synthetics. Brazil Journal of Genetics, 11, 355-367.

Ong'amo, G. O., Le Ru, B. P., Dupas, S., Moyal, P., Calatayud, P. A., \& Silvain, J. F. (2006). Distribution, pest status and agro-climatic preferences of lepidopteran stem borers of maize in Kenya. Annales de la Societe Entomologique de France, 42, 171-177.

Padhi, G., \& Sen, P. (2002). Evaluation of wild rice species against yellow stem borer (Scirpophaga incertulas Walk.). Journal of Applied Zoology Research, 13, 147-148.

Padhi, G. (2004). Biochemical basis of resistance in rice to yellow stem borer, Scirpophaga incertulas Walk. Madras Agricultural Journal, 91, 253-256.

Pimentel, D. (2002). Encyclopedia of pest management (pp. 481-487). New York, NY: Marcel Dekker Inc. http://dx.doi.org/10.1201/NOE0824706326

Santiago, R., Souto, X. C., Sotelo, J., Butrón, A., \& Malvar, R. A. (2003). Relationship between maize stem structural characteristics and resistance to pink stem borer (Lepidoptera: Noctuidae) attack. Journal of Economic Entomology, 96, 1563-1570. http://dx.doi.org/10.1603/0022-0493-96.5.1563

Sarwar, M. (2012). Management of rice stem borers (Lepidoptera: Pyralidae) through host plant resistance in early, medium and late plantings of rice (Oryza sativa L.). Journal of Cereals and Oil seeds, 3, 10-14. http://dx.doi.org.10.5897/JCO11.042

SAS. (2003). Proceedings of the Twenty-Eighth Annual SAS ${ }^{\circledR}$ Users Group International Conference. Cary, NC, USA: SAS Institute Inc.

Tefera, T., Mugo, S. Beyene, Y., Karaya, H., \& Tende, R. (2011). Grain yield, stem borer and disease resistance of new maize hybrids in Kenya. African Journal of Biotechnology, 10, 4777-4788.

\section{Copyrights}

Copyright for this article is retained by the author(s), with first publication rights granted to the journal.

This is an open-access article distributed under the terms and conditions of the Creative Commons Attribution license (http://creativecommons.org/licenses/by/3.0/). 